\title{
PENGEMBANGAN MODUL BERBASIS PENELITIAN ANALISIS AKTIVITAS FOSFORILASI PROTEIN MEMBRAN SPERMATOZOA KAMBING UNTUK MATAKULIAH TEKNIK ANALISIS BIOLOGI MOLEKULER
}

\author{
Alif Yanuar Zukmadini ${ }^{*}$, Umie Lestari², Murni Sapta Sari ${ }^{2}$ \\ ${ }^{1}$ Program Studi S-1 Pendidikan Biologi, Fakultas Keguruan dan Ilmu Pendidikan, Universitas Bengkulu \\ ${ }^{2}$ Program Studi S-2 Pendidikan Biologi, Program Pascasarjana, Universitas Negeri Malang \\ email :ayzukmadini@unib.ac.id
}

\begin{abstract}
Abstrak
Penelitian ini bertujuan untuk 1) menghasilkan modul berbasis penelitian analisis aktivitas fosforilasi protein membran spermatozoa kambing;2) untuk mengetahui aktivitas fosforilasi protein membran spermatozoa kambing PE dan Boer. Penelitian ini merupakan penelitian pengembangan yang menggunakan model pengembangan Borg \& Gall (1983) yang dibatasi sampai lima tahap yaitu, research and information collecting, planning, develop preliminary form of product, preliminary field testing, dan main product revision. Analisis aktivitas fosforilasi protein membran spermatozoa dilakukan dengan beberapa prosedur laboratorium yaitu, isolasi protein, elektroforesis, elektroelusi protein $43 \mathrm{kDa}$, dan uji aktivitas fosforilasi. Metode penelitian ini adalah deskriptif kuantitatif yang menggunakan instrumen berupa lembar validasi. Hasil validasi menunjukkan bahwa persentase kevalidan modul dari ahli materi sebesar 95,40\%, dari ahli bahan ajar sebesar 99,49\% dan dari uji coba kelompok kecil sebesar 86,35\%. Keseluruhan persentase yang diperoleh termasuk ke dalam kategori valid. Hasil penelitian mengenai aktivitas fosforilasi protein 43 kDa menunjukkan bahwa jumlah ATP yang difosforilasi pada protein membran spermatozoa kambing PE sebesar 179 ppm, sedangkan pada kambing Boer sebesar 159,5 ppm. Unit aktivitas fosforilasi protein $43 \mathrm{kDa}$ pada kambing PE sebesar $69,29 \times 10^{-2} \mu \mathrm{mol} / \mathrm{mL}$.menit, sedangkan pada kambing Boer sebesar $61,61 \times 10^{-2} \mu \mathrm{mol} / \mathrm{mL} . \mathrm{menit}$.
\end{abstract}

Keywords : Modul berbasis penelitian, aktivitas fosforilasi, teknik analisis biologi molekuler

\section{Abstract}

This research aimed 1) to produce research-based module analysis of phosphorylation activity in goat spermatozoa membrane protein; 2) to know phosphorylation activity of goat spermatozoa membrane protein in Peranakan etawa (PE) and Boer goat. This research was a development research that used development model from Borg \& Gall (1983) that limited to five stages namely, research and information collecting, planning, develop preliminary form of product, preliminary field testing, and main product revision. Analysis of phosphorylation activity in goat spermatozoa membrane protein was conducted by some of laboratory procedures, they were isolation of protein, electrophoresis SDS-PAGE, electroelution, and phosphorylation activity test. Method of this research was descriptive quantitatif that used validation sheetinstrument. The results of validation showed the percentage of validity module from material expert was $95.40 \%$, from teaching material expert was $99.49 \%$, and from small group trial was $86.35 \%$. All percentage obtained fall into the category of very valid. The result of research in phosphorylation activity of protein $43 \mathrm{kDa}$ showed the number of ATP was phosphorylated in PE spermatozoa membrane protein was $179 \mathrm{ppm}$, at the Boer was $159.5 \mathrm{ppm}$. Unit activity of protein phosphorylation $43 \mathrm{kDa}$ at PE was $69.29 \times 10^{-2}$ $\mathrm{mol} / \mathrm{mL}$.menit, while at the Boer was $61.61 \times 10^{-2} \mu \mathrm{mol} / \mathrm{mL}$.menit.

Keywords: Module-based research, phosphorylation Activity, Molecular Biology Analysis Technique 


\section{PENDAHULUAN}

Perkembangan ilmu pengetahuan dan teknologi terutama di bidang biologi tidak lepas dari peranan pendidikan di perguruan tinggi. Pendidikan tinggi merupakan kelanjutan pendidikan menengah yang diselenggarakan untuk menyiapkan peserta didik menjadi anggota masyarakat yang memiliki kemampuan akademik dan profesional yang dapat menerapkan, mengembangkan, dan atau menciptakan ilmu pengetahuan, teknologi, dan kesenian (Kepmendiknas No. 232/U/2000). Universitas Negeri Malang sebagailembaga penyelenggara pendidikan tinggi program studi Biologi memiliki tujuan untuk mempersiapkan lulusan biologi yang prospektif terhadap dunia sains (Katalog Biologi UM, 2013). Upaya yang dilakukan untuk mencapai tujuan pendidikan tinggi tersebut adalah mahasiswa diwajibkan untuk menempuh matakuliah Teknik Analisis Biologi Molekuler. Matakuliah ini merupakan matakuliah keahlian dan keterampilan (MKK) yang memberikan bekal kepada mahasiswa biologi untuk terampil dalam melakukan teknik-teknik molekuler protein,sehingga dapat digunakan untuk menciptakan dan mengembangkan ilmu pengetahuan terutama di bidang bioteknologi. Thieman \& Palladino (2013) menyatakan teknik-teknik molekuler merupakan salah satu bagian dari cabang ilmu biologi sel dan molekuler yang yang sangat mendukung keberhasilan penerapan bioteknologi pada berbagai bidang kehidupan. Adanya peranan matakuliah TABM untuk membantu mempersiapkan lulusan perguruan tinggidalam mengembangkan dan menciptakan IPTEK, makasalah satukegiatan pembelajaran dilakukan melalui kegiatan praktikum serta didukung oleh penggnaan bahan ajar.

Bahan ajar merupakan salah satu segala bentuk bahan baik berupa informasi, alat, maupun teks yang disusun secara sistematis, menampilkan kompetensi yang akan dikuasai oleh mahasiswa, dan digunakan dalam proses pembelajaran (Prastowo, 2011). Berdasarkan analisis kebutuhan bahan ajar dan wawancara dengan dosen pengampu matakuliah TABM, diperoleh informasi bahwa bahan ajar yang digunakan hanya menyajikan materi mengenai prosedur teknik analisis molekuler secara umum dan belum mengakomodir kegiatan dan aktivitas mahasiswa selama praktikum. Selain itu, materi yang terdapat pada bahan ajar yang digunakan selama ini tidak menampilkan materi yang aplikatif, padahal teknik-teknik analisis yang dipelajari oleh mahasiswa pada matakuliah TABM dapat dimanfaatkan di bidang bioteknologi peternakan. Pemanfaatan prosedur teknik analisis protein yang dipelajari oleh mahasiswa pada matakuliah TABM dapat dimanfaatkan untuk mengetahui kualitas sperma kambing secara molekuler untuk inseminasi buatan.

Keberhasilan inseminasi buatan pada ternak kambing saat ini masih berada di bawah angka 40\% (Tambing \& Sariubang, 2008). Keberhasilan inseminasi buatan tersebut dipengaruhi oleh beberapa faktor salah satunya kualitas sperma (Pamungkas, 2009). Indikator kualitas sperma yang digunakan masih terbatas pada aspekmakroskopis dan mikroskopis, sangat terbatas sekali informasi mengenai kualitas sperma secara molekuler. Analisis kualitas sperma secara molekuler dapat diketahui dengan menerapkan teknikteknik analisis protein yang dipelajari pada matakuliah TABM dengan cara melakukan analisis aktivitas fosforilasi protein membran spermatozoa kambing. Analisis aktivitas fosforilasi protein berperan penting dalam menyediakan energi bagi sperma untuk proses kapasitasi dan reaksi akrosom pada saat membuahi sel telur. Adanya peranan aktivitas fosforilasi dalam membuahi sel telur sangat mendukung keberhasilan fertilisasi (Nath \& Majumder, 2007).

Berkaitan dengan adanya peranan teknik analisis protein yang dipelajari pada matakuliah TABM, namun belum terakomodir dengan adanya penggunaan bahan ajar yang dapat memandu mahasiswa untuk belajar secara mandiri terutama pada saat kegiatan praktikum, maka dikembangkan modul 
berbasis penelitian analisis aktivitas fosforilasi protein membran spermatozoa kambing. Depdiknas (2008) menyatakan bahwa modul merupakan bahan ajar cetak yang ditulis dengan tujuan agar peserta didik dapat belajar secara mandiri tanpa atau dengan bimbingan pendidik. Pengembangan modul berbasis penelitian juga pernah dilakukan oleh Purnama (2014) yang mengembangkan modul analisis proteomik untuk matakuliah TABM. Pengembangan bahan ajar berbasis penelitian saat ini semakin banyak dilakukan karena bahan ajar berbasis penelitian mampu menumbuhkan jalinan yang kuat antara riset dan pengajaran di jenjang pendidikan tinggi (Brew, 2007).

Penelitian ini bertujuan untuk (1) menghasilkan modul berbasis penelitian analisis aktivitas fosforilasi protein membran spermatozoa kambing yang telah tervalidasi sehingga untuk digunakan pada matakuliah TABM di Jurusan Biologi Universitas Negeri Malang, (2) mengetahui aktivitas fosforilasi protein membran spermatozoa kambing PE dan kambing Boer.Modul berbasis penelitian diharapkan dapat membantu mahasiswa dalam melakukan kegiatan pembelajaran secara mandiri terutama pada saat kegiatan praktikum, sehingga mahasiswa yang akan menjadi lulusan program studi biologi mampu memanfatkan teknik analisis molekuler dalam memecahkan permasalahan di masyarakat terutama dalam mengatasi keterbatasan informasi mengenai kualitas sperma secara molekuler.

\section{METODE}

Penelitian ini merupakan penelitian pengembangan yang dilakukan untuk mengembangkan modul berbasis penelitian analisis aktivitas fosforilasi protein membran spermatozoa kambing. Pengembangan modul berbasis penelitian dilakukan menggunakan model pengembangan Borg \&Gall (1983) yang dibatasi sampai pada lima tahap pengembangan yaitu research and information collecting, planning, develop preliminary form of product, preliminary field testing, dan main product revision. Pada tahap Research and information colecting dilakukan analisis kebutuhan bahan ajarmelalui wawancara dengan dosen pengampu dan menyebarkan angket kepada mahasiswa TABM. Pada tahap ini juga dilakukan review literatur dan dilakukan penelitian laboratorium dalam rangka mengumpulkan informasi mengenaiaktivitas fosforilasi protein membran spermatozoa kanbing. Prosedur laboratorium yang dilakukan terdiri dari isolasi protein, elektroforesis SDS-PAGE, elektroelusi, dan uji aktivitas fosforilasi. Penelitian mengenai analsis aktivitas fosforilasi dilakukan dengan terlebih dahulu mengisolasi protein membran spermatozoa dari kambing PE dan Boer, kemudian isolat protein digunakan untuk diketahui berat molekulnya menggunakan metode elektroforesis SDS-PAGE. Hasil dari elektroforesis SDS-PAGE adalah pita protein dengan berat molekul tertentu. Berat molekul pita protein dihitung menggunakan rumus:

$$
\mathrm{R}_{\mathrm{f}}=\frac{\text { Jarak pergerakan pita protein dari tempat awal }}{\text { Jarak pergerakan warna pelacak dari tempat awal }}
$$

(Fatchiyah dkk, 2011)

Pita protein hasil elektroforesis dengan berat molekul $43 \mathrm{kDa}$ kemudian dielektroelusi. Isolat protein $43 \mathrm{kDa}$ kemudian dihitung absorbansinya menggunakan nanodrop spektrofotometer UV-Vis pada panjang gelombang $260 \mathrm{~nm}$. Nilai absorbansi kemudian dikonversi menggunakan kurva baku ATP. Konsentrasi ATP yang telah diketahui kemudian dihitung jumlah ATP yang bereaksi menggunakan rumus: 
Setelah diketahui jumlah ATP yang bereaksi kemudian dihitung nilai unit aktivitas fosforilasinya menggunakan rumus:

$$
\text { Unit aktivitas }=\frac{\left[A T P_{\text {aval }}-A T P_{\text {sisa }}\right]}{M r A T P} \times \frac{V}{p \cdot q} \times f p
$$

(Aulanni'am, 2004)

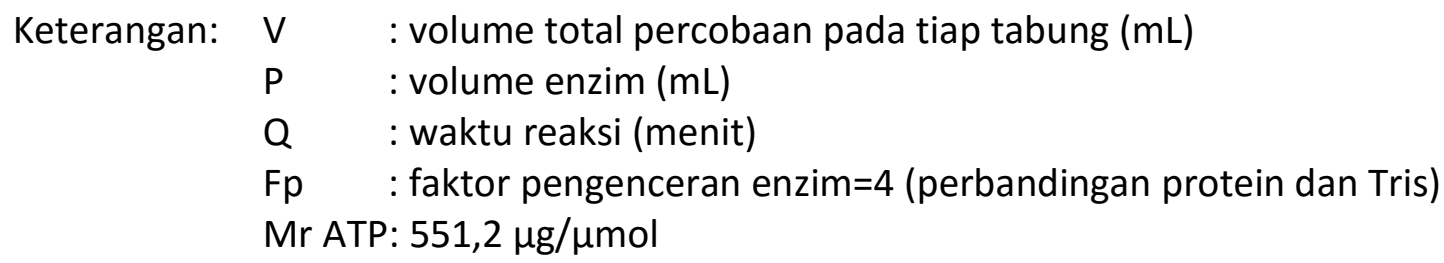

Tahap planning dilakukan untuk menetapkan indikator dan tujuan pembelajaran yang akan dikembangkan di dalam modul, serta menyusun lembar validasi untuk ahli materi, ahli bahan ajar, dan uji coba kelompok kecil. Tahap develop preliminary form of product dilakukan untuk mengembangkan modul sesuai dengan sistematika yang dibuat dan memuat prosedur teknik analisis aktivitas fosforilasi protein membran spermatozoa kambing. Tahap preliminary field testing dilakukan untuk mengetahui tingkat kelayakan modul yang dikembangkan. Pada tahap ini dilakukan validasi ahli materi, ahli bahan ajar, dan uji coba kelompok kecil yang melibatkan 10 orang mahasiswa yang telah menempuh matakuliah TABM. Tahap main product revision dilakukan untuk merevisi produk berdasarkan saran dan masukkan dari ahli materi, ahli bahan ajar, dan mahasiswa. Subjek uji coba dalam penelitian ini adalah ahli materi, ahli bahan ajar, dan mahasiswa.

Modul berbasis penelitian yang dikembangkan mengacu pada sistematika pengembangan modul menurut Depdiknas (2008) yang terdiri dari bagian pendahuluan, kegiatan pembelajaran, dan penutup. Komponen yang terdapat di dalam setiap kegiatan pembelajaran terdiri dari tujuan kegiatan pembelajaran, materi, rangkuman, lembar kegiatan mahasiswa, tes formatif, umpan balik (self assessment), kunci jawaban tes formatif. Jenis data penelitian ini adalah data kuantitatif dan data kualitatif. Data kuantitatif meliputi skor validasi oleh ahli materi, ahli bahan ajar, uji coba kelompok kecil, serta data mengenai aktivitas fosforilasi pada protein membran spermatozoa kambing. Data kualitatif meliputi kritik dan saran dari validator dan uji coba kelompok kecil. Instrumen yang digunakan yaitu lembar validasi, adapun teknik analisis data yang digunakan yaitu dengan menghitung persentase setiap aspek penilaian dari lembar validasi menggunakan rumus:

$P=\frac{\sum x}{\sum x i} x 100 \%$ (Arikunto, 2012)

Keterangan:

$\mathrm{P}=$ Persentase Kevalidan

$\Sigma x \quad=$ Jumlah seluruh skor jawaban responden per item

$\Sigma x i=$ Jumlah seluruh skor ideal per item

$100 \%=$ Konstanta

Berdasarkan perhitungan persentase kevalidan yang diperoleh, selanjutnya dilakukan pengambilan keputusan mengenai kevalidan modul yang mengacu pada Tabel 1.

Tabel 1. Kriteria Kevalidan Data dan Pengambilan Keputusan Revisi Modul

\begin{tabular}{ccc}
\hline Skala Nilai (\%) & Keterangan & $\begin{array}{c}\text { Keputusan } \\
\text { Uji }\end{array}$ \\
\hline $86-100$ & Sangat valid & Sangat \\
& & layak dan \\
& tidak revisi \\
& & jika \\
& & mencapai \\
& & $100 \%$ \\
$71-85$ & Valid & Layak \\
& & namun \\
& & tetap \\
& & dilakukan \\
& & revisi kecil \\
& & Cukup layak \\
& & dan perlu \\
& & revisi besar
\end{tabular}


41-55

$$
\begin{array}{cc}
\text { Kurang valid } & \begin{array}{c}
\text { Kurang } \\
\text { layak dan } \\
\text { perlu revisi } \\
\text { besar }
\end{array}
\end{array}
$$

(Sumber: Akbar, 2013)

\section{HASIL DAN PEMBAHASAN}

Berdasarkan penelitian dan pengembangan yang dilakukan terhadap modul berbasis penelitian analisis aktivitas fosforilasi protein membran spermatozoa kambing, maka diperoleh dua data hasil penelitian dan pengembangan yaitu data mengenai analisis aktivitas fosforilasi protein membran spermatozoa kambing dan data mengenai uji coba produk pengembangan, kedua data dijabarkan sebagai berikut

\section{Data Hasil Analisis Aktivitas Fosforilasi Protein}

Hasil elektroforesis SDS-PAGE menunjukkan bahwa protein membran spermatozoa yang terdapat pada kambing PE dan Boer telah
25-20

Sangat kurang valid

Tidak layak dan perlu revisi besar

terpisah berdasarkan berat molekulnya. Pada kambing $P E$, protein yang muncul terdapat pada berat molekul 55, 43, 38, 32, 21, dan 14 $\mathrm{kDa}$. Pada kambing Boer, protein yang muncul terdapat pada berat molekul 43 dan 14 kDa. Protein yang telah terpisah berdasarkan berat molekulnya dapat dilihat dari profil pita protein yang terdapat pada gel hasil elektroforesis. Penampakan profil pita protein dari gel hasil elektroforesis kemudian dibuatkan zimogramnya yang bertujuan untuk mempermudah pola pembacaan pita protein. Profil pita protein membran spermatozoa kambing PE dan Boer beserta zimogramnya dapat dilihat pada Gambar 1.

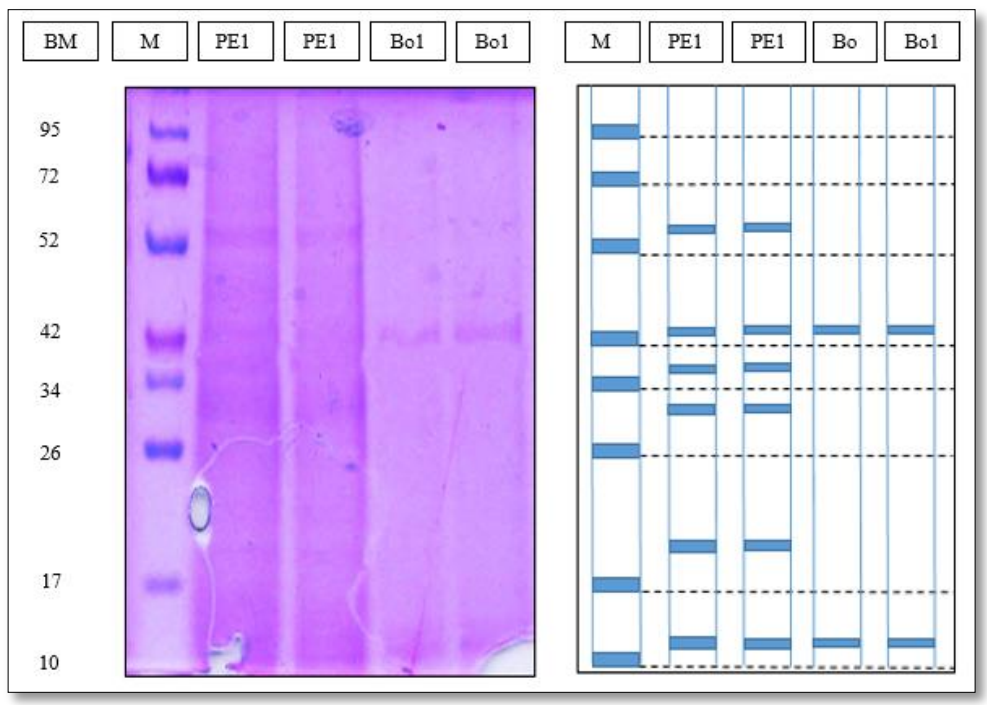

(a)

(b)

Gambar 1 (a) Profil Pita Protein Membran Spermatozoa Kambing Hasil Elektroforesis SDS-PAGE dan (b) Zimogram Pita Protein Membran Spermatozoa Kambing Hasil Elektroforesis SDS-PAGE

Keterangan: BM : Berat Molekul (kDa)

M : Marker Protein

PE : Pita Protein Kambing PE

Bo : Pita Protein Kambing Boer
Hasil elektroforesis SDS-PAGE memperlihatkan adanya kesamaan berat molekul pada kedua jenis kambing, yaitu pada protein dengan berat molekul $43 \mathrm{kDa}$ dan 14 kDa. Meskipun terdapat dua jenis protein dengan berat molekul yang sama pada kedua spesies kambing, namun hanya digunakan satu protein dengan berat molekul yang sama dan telah teridentifikasi memiliki aktivitas fosforilasi. Nath \& Majumder (1999) yang 
menyatakan bahwa salah satu protein yang memiliki aktivitas fosforilasi pada membran spermatozoa kambing adalah protein 43 kDa.Berdasarkan literatur tersebut, maka protein yang digunakan untuk uji aktivitas fosforilasi dari kambing PE dan kambing Boer adalah protein dengan berat molekul $43 \mathrm{kDa}$. Data hasil uji aktivitas fosforilasi dapat dilihat pada Tabel 2.

Tabel 2. Nilai Aktivitas Fosforilasi Protein Membran Spermatozoa Kambing PE dan Boer

\begin{tabular}{ccccc}
\hline Spesies & $\begin{array}{c}\text { ATP mula-mula } \\
\text { (ppm) }\end{array}$ & $\begin{array}{c}\text { ATP sisa } \\
(\mathbf{p p m})\end{array}$ & $\begin{array}{c}\text { ATP yang bereaksi } \\
(\mathbf{p p m})\end{array}$ & $\begin{array}{c}\text { Unit aktivitas } \\
(\boldsymbol{\mu m o l} / \mathbf{m L} . \mathbf{m e n i t})\end{array}$ \\
\hline PE & 186 & 7 & 179 & $69,29 \times 10^{-2}$ \\
Boer & 186 & 26,5 & 159,5 & $61,61 \times 10^{-2}$ \\
\hline
\end{tabular}

\section{Data Hasil Uji Coba Produk}

Produk yang diperoleh dari hasil penelitian dan pengembangan berupa modul yang memuat prinsip dan prosedur teknik yang digunakan dalam analisis aktivitas fosforilasi. Prosedur-prosedur teknik yang dilakukan meliputi isolasi protein dan penentuan kadar protein, elektroforesis dan perhitungan berat molekul elektroforesis, elektroelusi, dan uji aktivitas fosforilasi.
Keseluruhan prosedur teknik tersebutdijadikan sebagai materi untuk mengembangkan modul berbasis penelitian analisis aktivitas fosforilasi protein membran spermatozoa kambing. Pengembangan produk dilakukan berdasarkan sistematika pengembangan modul yang telah dirancang, adapun sistematika produk dapat dilihat pada Tabel 3.

Tabel 3. Sistematika Desain Pengembangan Modul Berbasis Penelitian Analisis Aktivitas Fosforilasi Protein Membran Spermatozoa Kambing

\begin{tabular}{|c|c|c|}
\hline Bagian Modul & \multicolumn{2}{|l|}{ Konten } \\
\hline \multirow[t]{8}{*}{ Bagian Awal } & \multicolumn{2}{|l|}{ Kata Pengantar } \\
\hline & \multicolumn{2}{|l|}{ Daftar Isi } \\
\hline & \multicolumn{2}{|l|}{ Daftar Singkatan } \\
\hline & \multicolumn{2}{|l|}{ Daftar Tabel } \\
\hline & \multicolumn{2}{|l|}{ Daftar Gambar } \\
\hline & \multicolumn{2}{|c|}{ Kompetensi Dasar, Indikator kompetensi, dan Tujuan Pembelajaran } \\
\hline & \multicolumn{2}{|c|}{ Peta Materi } \\
\hline & \multicolumn{2}{|l|}{ Pendahuluan } \\
\hline \multirow[t]{4}{*}{ Pengantar } & \multicolumn{2}{|c|}{ Deskripsi Modul } \\
\hline & \multicolumn{2}{|c|}{ Petunjuk penggunaan modul } \\
\hline & \multicolumn{2}{|c|}{ Petunjuk keselamatan kerja laboratorium } \\
\hline & \multicolumn{2}{|c|}{ Perkembangan dan Konsep Dasar Teknik Analisis Protein } \\
\hline \multirow[t]{7}{*}{ Bagian inti } & \multicolumn{2}{|c|}{$\begin{array}{l}\text { Berisi materi yang dikembangkan berdasarkan penelitian laboratorium mengenai } \\
\text { analisis aktivitas fosforilasi protein membran spermatozoa kambing yang terdiri } \\
\text { dari: }\end{array}$} \\
\hline & Kegiatan laboratorium I & Pengenalan alat, bahan kimia, dan larutan \\
\hline & Kegiatan laboratoriumll & Isolasi dan penentuan kadar protein \\
\hline & Kegiatan laboratorium III & Elektroforesis SDS PAGE \\
\hline & Kegiatan laboratoriumIV & Perhitungan Berat Molekul Protein \\
\hline & Kegiatan laboratorium V & Elektroelusi \\
\hline & Kegiatan laboratorium VI & Uji Aktivitas Fosforilasi \\
\hline \multirow[t]{5}{*}{ Bagian Akhir } & \multicolumn{2}{|l|}{ Tes Sumatif } \\
\hline & \multicolumn{2}{|l|}{ Kunci jawaban tes } \\
\hline & \multicolumn{2}{|l|}{ Hasil Penelitian } \\
\hline & \multicolumn{2}{|l|}{ Daftar Rujukan } \\
\hline & \multicolumn{2}{|l|}{ Glosarium } \\
\hline
\end{tabular}


Materi pada setiap bab terdiri dari komponen-komponen yang dapat memandu mahasiswa untuk belajar secara mandiri. Komponen dalam setiap kegiatan pembelajaran terdiri dari judul materi, tujuan pembelajaran, uraian materi, rangkuman materi, kegiatan/aktivitas mahasiswa, tes formatif, kunci jawaban tes, dan umpan balik (self assessment). Produk yang telah dikembangkan kemudian divalidasi oleh ahli materi, ahli bahan ajar, dan dilakukan uji coba kelompok kecil untuk memperoleh data mengenai kelayakan modul. Hasil penilaian oleh ahli materi, bahan ajar, dan mahasiwa berupa data kuantitatif dan kualitatif. Data kuantitatif berupa persentase kevalidan modul, sedangkan data kualitatif berupa kritik dan saran yang kemudian dijadikan sebagai bahan pertimbangan untuk merevisi modul. Hasil persentase penilaian modul oleh ahli materi dapat dilihat pada Tabel 4.

oleh Ahli Materi

\begin{tabular}{|c|c|c|c|c|}
\hline $\begin{array}{c}\text { Aspek } \\
\text { penilaian }\end{array}$ & $\begin{array}{c}\text { Total } \\
\text { skor yang } \\
\text { diperoleh }\end{array}$ & $\begin{array}{l}\text { Total } \\
\text { Skor } \\
\text { ideal }\end{array}$ & $\begin{array}{c}\text { Persentase } \\
\text { (\%) }\end{array}$ & Kategori \\
\hline Isi/materi & 41 & 44 & 93,18 & $\begin{array}{l}\text { Sangat } \\
\text { valid }\end{array}$ \\
\hline Penyajian & 91 & 96 & 94,79 & $\begin{array}{l}\text { Sangat } \\
\text { valid }\end{array}$ \\
\hline Bahasa & 55 & 56 & 98,21 & $\begin{array}{l}\text { Sangat } \\
\text { valid }\end{array}$ \\
\hline $\begin{array}{c}\text { Total } \\
\text { keseluruhan }\end{array}$ & 187 & 196 & 95,40 & $\begin{array}{c}\text { Sangat } \\
\text { valid }\end{array}$ \\
\hline
\end{tabular}

Hasil persentase penilaian modul oleh ahli bahan ajar dapat dilihat pada Tabel 5.

Tabel 5Hasil Persentase Penilaian Modul oleh Ahli Bahan Ajar

\begin{tabular}{|c|c|c|c|c|}
\hline $\begin{array}{c}\text { Aspek } \\
\text { penilaian }\end{array}$ & $\begin{array}{c}\text { Total } \\
\text { skor yang } \\
\text { diperoleh }\end{array}$ & $\begin{array}{l}\text { Total } \\
\text { Skor } \\
\text { ideal }\end{array}$ & $\begin{array}{c}\text { Persentase } \\
\text { (\%) }\end{array}$ & Kategor \\
\hline $\begin{array}{l}\text { Ukuran fisik } \\
\text { modul }\end{array}$ & 8 & 8 & 100 & $\begin{array}{c}\text { Sangat } \\
\text { valid }\end{array}$ \\
\hline $\begin{array}{l}\text { Desain kulit } \\
\text { modul }\end{array}$ & 72 & 72 & 100 & $\begin{array}{c}\text { Sangat } \\
\text { valid }\end{array}$ \\
\hline $\begin{array}{l}\text { Desain isi } \\
\text { modul }\end{array}$ & 115 & 116 & 99,14 & $\begin{array}{c}\text { Sangat } \\
\text { valid }\end{array}$ \\
\hline
\end{tabular}

\begin{tabular}{ccccc}
\hline $\begin{array}{c}\text { Total } \\
\text { keseluruhan }\end{array}$ & 195 & 196 & 99,49 & $\begin{array}{c}\text { Sangat } \\
\text { Valid }\end{array}$ \\
\hline
\end{tabular}

Hasil persentase penilaian modul dari uji coba kelompok kecil yang melibatkan mahasiswa yang telah menempuh matakuliah TABM dapat dilihat pada Tabel 6 .

Tabel 6Hasil Persentase Penilaian Modul dari Uji Coba Kelompok Kecil

\begin{tabular}{|c|c|c|c|c|}
\hline $\begin{array}{c}\text { Aspek } \\
\text { Penilaian }\end{array}$ & $\begin{array}{l}\text { Total skor } \\
\text { yang } \\
\text { diperoleh }\end{array}$ & $\begin{array}{l}\text { Total } \\
\text { Skor } \\
\text { ideal }\end{array}$ & $\begin{array}{c}\text { Persentase } \\
\text { (\%) }\end{array}$ & Kategori \\
\hline Penyajian & 105 & 120 & 87,5 & $\begin{array}{c}\text { Sangat } \\
\text { valid }\end{array}$ \\
\hline Materi & 139 & 160 & 86,87 & $\begin{array}{c}\text { Sangat } \\
\text { valid }\end{array}$ \\
\hline $\begin{array}{c}\text { Self } \\
\text { instructional }\end{array}$ & 170 & 200 & 85 & $\begin{array}{l}\text { Sangat } \\
\text { valid }\end{array}$ \\
\hline $\begin{array}{c}\text { Total } \\
\text { keseluruhan }\end{array}$ & 480 & 414 & 86,35 & $\begin{array}{l}\text { Sangat } \\
\text { Valid }\end{array}$ \\
\hline
\end{tabular}

Berdasarkan persentase yang diperoleh dari hasil penilaian oleh ahli materi, bahan ajar, dan uji coba kelompok kecil diketahui bahwa modul berbasis penelitian analisis aktivitas fosforilasi protein membran spermatozoa kambing termasuk ke dalam kategori valid dan tidak diperlukan revisi besar. Meskipun tidak dilakukan revisi secara keseluruhan, namun modul tetap perlu diperbaiki berdasarkan kritik dan saran dari ahli materi, ahli bahan ajar, dan mahasiswa. Kritik dan saran yang diperoleh merupakan data kualitatif yang sekaligus dijadikan sebagai bahan pertimbangan untuk memperbaiki produk.

Menurut ahli materi hal yang perlu perbaiki, yaitu judul sebaiknya diganti sesuai dengan isi modul, pemenggalan bahan/materi perlu dilakukan untuk memberi arahan pembaca. Menurut ahli bahan ajar hal yang perlu diperbaiki adalah warna cover, penambahan penilaian sikap, penambahan keterangan mengenai petunjuk risiko kerja laboratorium, dan peringatan tentang konsistensi langkah kerja. Berdasarkan hasil penilaian oleh uji 
coba kelompok kecil sebaiknya warna cover halaman dirubah dengan tampilan yang lebih menarik, ukuran header diperkecil, serta kata kerja yang mendeskripsikan prosedur laboratorium menggunakan kata kerja pasif. Berdasarkan beberapa pertimbangan dari ahli materi, ahli bahan ajar, dan mahasiswa maka telah dilakukan perbaikan modul berdasarkan kritik dan saran yang disampaikan.

Penelitian pengembangan yang diawali dari penelitian laboratorium mengenai aktivitas fosforilasi protein membran spermatozoa kambing, memberikan hasil berupa data aktivitas fosforilasi yang terjadi pada protein membran spermatozoa. Data hasil penelitian aktivitas fosforilasi protein membran spermatozoa kambing dapat dilihat dari banyaknya ATP yang bereaksi dan unit aktivitas fosforilasinya. Jumlah ATP yang bereaksi pada protein $43 \mathrm{kDa}$ membran spermatozoa kambing $P E$ sebesar 179 ppm, sedangkan pada kambing Boer sebesar 159,5 ppm. Jumlah ATP yang bereaksi menunjukkan banyaknya jumlah gugus fosfat yang difosforilasi atau dipindahkan ke suatu ke protein substrat. Hal ini sesuai dengan pernyataan Sherwood (2014) yang menyatakan bahwa aktivitas fosforilasi merupakan penambahan atau pemindahan gugus fosfat ke suatu molekul protein substrat.

Unit aktivitas fosforilasi protein membran spermatozoa kambing, menunjukkan bahwa nilai unit aktivitas fosforilasi protein $43 \mathrm{kDa}$ pada protein membran spermatozoa kambing $\mathrm{PE}$ sebesar $69,29 \times 10^{-2} \mu \mathrm{mol} / \mathrm{mL}$.menit, sedangkan pada kambing Boer sebesar $61,61 \times 10^{-2} \mu \mathrm{mol} / \mathrm{mL}$.menit. Nilai unit aktivitas fosforilasi berkaitan dengan kemampuan protein dalam memfosforilasi gugus fosfat ke suatu protein substrat dalam setiap $\mathrm{mL}$.menit. Jika dihubungkan dengan jumlah gugus fosfat yang bereaksi, semakin banyak jumlah ATP yang bereaksi maka semakin meningkat unit aktivitas fosforilasi proteinnya. Adanya perbedaan jumlah gugus fosfat yang bereaksi pada kedua jenis protein kambing, menunjukkan bahwa jumlah gugus fosfat yang difosforilasi pada protein membran spermatozoa kambing PE lebih banyak dibandingkan dengan kambing Boer. Semakin banyaknya ATP yang difosforilasi, maka semakin banyak pula energi yang dibebaskan. Pembebasan energi akibat adanya aktivitas fosforilasi protein dikarenakan adanya reaksi hidrolisis yang menguraikan ATP menjadi ADP dan Pi yang terjadi pada protein fosforilasi (Campbell et al., 2008).

Energi yang dihasilkan oleh proten membran spermatozoa karena adanya aktivitas fosforilasiberperan penting dalam menyediakan energi bagi motilitas sperma terutama pada saat melakukan kapasitasi dan reaksi akrosom pada saat membuahi sel telur (Naz \&Rajesh, 2004). Jenis protein yang memiliki aktivitas fosforilasi pada protein $43 \mathrm{kDa}$ diduga merupakan protein kinase. Nath et al (2012) menyatakan bahwa aktivitas fosforilasi protein kinase yang terdapat pada membran spermatozoa kambing berperan penting dalam menyediakan energi motilitas sperma.Urner \& Sakkas (2003) menyatakan bahwa kemampuan sperma untuk melakukan motilitas progresif pada saat membuahi sel telur ditandai dengan adanya peningkatan aktivitas fosforilasi oleh protein tirosin kinase yang terjadi di bagian flagel atau ekor spermatozoa.

Adanya nilai aktivitas fosforilasi yang lebih tinggi pada kambing PE dibandingkan dengan Boer, menunjukkan bahwa peluang keberhasilan inseminasi buatan pada kambing PE lebih besar dibandingkan dengan kambing Boer, meskipun banyak faktor lain yang dapat mempengaruhi keberhasilan inseminasi buatan. Correa et al (1996) menyatakan bahwa keberhasilan program IB dapat dipengaruhi oleh beberapa faktor, yaitu kualitas ternak betina, keterampilan 
Inseminator dalam melakukan inseminasi, ketepatan waktu IB, deteksi berahi, handling semen dan kualitas semenNilai aktivitas fosforilasi protein yang lebih tinggi pada kambing PE dapat dipengaruhi oleh sifat genetik yang berhubungan dengan daya adaptasi kambing PE terhadap lingkungan. Suharno \& Syukur (2014) menyatakan bahwa kambing PE merupakan kambing hasil persilangan antara kambing Etawa dan kambing lokal (Kacang) yang memiliki daya adaptasi yang tinggi terhadap lingkungan Lokal Indonesia. Adanya perbedaan nilai aktivitas fosforilasi yang terdapat pada kedua jenis kambing diharapkan dapat memberikan informasi yang akurat mengenai kualitas sperma secara molekuler sehingga dapat memperbesar peluang keberhasilan inseminasi buatan.

Hasil penelitian mengenai analisis aktivitas fosforilasi protein membran spermatozoa kambing selanjutnya digunakan sebagai materi atau bahan untuk mengembangkan modul berbasis penelitian. Pengembangan modul berbasis penelitian analisis aktivitas fosforilasi protein membran spermatozoa kambing, dilakukan untuk memperoleh bahan ajar yang layak digunakan oleh mahasiswa pada matakuliah TABM. Modul yang dikembangkan berbasis penelitian telah diuji kelayakannya oleh validator ahli materi, ahli bahan ajar, dan uji coba kelompok kecil. Hasil validasi dan uji coba kelompok kecil menunjukkan bahwa modul yang dikembangkan termasuk ke dalam kategori sangat valid sehingga layak digunakan pada matakuliah TABM.

Modul berbasis penelitian memuat prosedur dan teknik analisis protein yang penerapannya dapat digunakan untuk mengetahui kualitas sperma secara molekuler. Materi mengenai isolasi protein, elektroforesis SDS-PAGE, elektroelusi, dan uji aktivitas fosforilasi yang terdapat di dalam modul merupakan materi yang dipelajari mahasiwa TABM. Materi mengenai prosedur teknik analisis protein yang terdapat di dalam modul ini diharapkan dapat membantu mahasiswa mengatasi keterbatasan bahan ajar berbasis penelitian. Adanya modul yang menjabarkan mengenai prosedur dan teknik analsis yang aplikatif, diharapkan dapat digunakan oleh mahasiswa untuk belajar secara mandiri dalam mengembangkan ilmu pengetahuan dan teknologi di bidang penelitian lainnya. Depdiknas (2008) menyatakan bahwa modul merupakan bahan ajar yang digunakan oleh peserta didik untuk dapat belajar secara mandiri dengan atau tanpa bimbingan instruktur pendidik.

Pengembangan modul yang dilakukan berbasis penelitian analisis aktivitas fosforilasi protein membran spermatozoa kambing menunjukkan bahwa modul bersifat kontekstual karena dapat digunakan oleh mahasiwa pada saat melakukan kegiatan praktikum mengenai analisis protein. Pernyataan tersebut sesuai dengan Depdiknas (2008) yang menyatakan bahwa salah satu karakteristik yang perlu diperhatikan dalam pengembangan modul adalah modul harus bersifat kontekstual dimana materi-materi yang disajikan berkaitan dengan suasana atau konteks tugas dan lingkungan penggunannya.

Materi pembelajaran yang terdapat di dalam modul tersaji secara berurutan sesuai dengan sistematika pengembangan modul yang telah dibuat. Adanya penyajian materi yang sistematis dan terstrukur antara bagian awal, isi, dan akhir dapat mengarahkan mahasiswa untuk belajar secara mandiri. Pernyataan ini didukung oleh Amin, dkk (2006) bahwa modul sebagai suatu unit bahan ajar dirancang secara khusus untuk dipelajari secara mandiri yang disusun secara sistematis, mengacu pada pembelajaran yang jelas dan terukur, memuat tujuan pembelajaran, bahan, kegiatan untuk mencapai tujuan, dan evaluasi terhadap pencapaian tujuan pembelajaran. 
Setiap kegiatan pembelajaran yang terdapat di dalam modul memuat komponen seperti adanya tujuan pembelajaran, uraian materi, rangkuman, kegiatan mahasiswa, tes formatif, dan umpan balik. Materi yang disajikan di dalam modul merupakan materi yang dikemas secara utuh, yang penggunaannya tidak bergantung kepada media pembelajaran lain, serta sesuai dengan perkembangan ilmu pengetahuan dan teknologi. Jika dilihat dari aspek penyajian materi dan bahasa yang digunakan, modul mampu memaparkan informasi yang dapat membantu penggunanya untuk memahami materi pembelajaran yang terdapat di dalam modul. Karakteristik penyajian materi yang terdapat pada modul ini, menunjukkan bahwa modul berbasis penelitian analisis aktivitas fosforilasi protein membran spermatozoa kambing yang dikembangkan sesuai dengan karakteristik pengembangan modul menurut Depdiknas (2008), yang menyatakan bahwa karakteristik pengembangan modul adalah self instructional, self contained, stand alone, adaptive, dan user friendly.

Pengembangan modul berbasis penelitian yang materinya dikembangkan sesuai dengan dengan indikator kompetensi matakuliah TABM, menunjukkan bahwa modul ini memiliki relevansi dengan kurikulum perguruan tinggi. Adanya relevansi tersebut maka modul berbasis penelitian analisis aktivitas fosforilasi protein membran spermatozoa kambing dapat digunakan pada matakuliah TABM sekaligus membantu mahasiswa mengetahui keterkaitan antara materi pembelajaran dengan hasil penelitian yang dilakukan. Mulyasa (2006) menyatakan bahwa keunggulan modul dalam pembelajaran adalah modul memiliki relevansi dengan kurikulum yang dapat ditunjukkan dengan adanya tujuan dan cara pencapaiannya, sehingga peserta didik dapat mengetahui keterkaitan antara pembelajaran dan hasil yang diperoleh.
Pengembangan bahan ajar berupa modul berbasis penelitian analisis aktivitas fosforilasi protein membran spermatozoa yang dilakukan memiliki keunggulan tersendiri karena dapat membantu peranan perguruan tinggi dalam mengembangkan pendidikan dan ilmu pengetahuan, sekaligus membuat benang penghubung antara riset dan pembelajaran. Hal ini sesuai dengan pernyataan Brew (2007) bahwa adanya bahan ajar berbasis penelitian mampu menumbuhkan jalinan yang kuat antara riset dan pengajaran di jenjang pendidikan tinggi.

Keunggulan dari modul berbasis penelitian ini adalah materi yang dikembangkan berasal dari hasil kegiatan penelitian analisis aktivitas fosforilasi protein membran spermatozoa kambing, modul bersifat kontekstual, modul memuat penilaian tidak hanya pada aspek kognitif dan psikomotor, namun dilengkapi juga dengan penilaian aspek afektif dan spiritual. Modul sebagai bahan ajar selain dapat digunakan pada matakuliah TABM, juga mampu memberikan informasi mengenai dasar penentuan kualitas sperma secara molekuler ditinjau dari aktivitas fosforilasi yang terdapat pada membran spermatozoa kambing. Selain memiliki keunggulan, modul ini juga memiliki kelemahan. Kelemahan dari modul ini yaitu hanya memuat materi dan prosedur analisis protein $43 \mathrm{kDa}$, yang belum diketahui secara pasti jenis proteinnya karena masih diduga merupakan protein kinase. Sebaiknya dilakukan pengembangan produk dengan menganalisis pita protein yang berbeda berat molekulnya dan dilakukan identifikasi jenis protein menggunakan prosedur laboratorium lebih lanjut. Prosedur laboratorium lebih lanjut tersebut dapat ditambahkan sebagai materi di dalam modul berbasis penelitian. 


\section{PENUTUP}

\section{Simpulan}

Kesimpulan dari penelitian ini yaitu 1 ) modul berbasis penelitian analisis aktivitas fosforilasi protein membran spermatozoa yang dikembangkan merupakan modul yang valid dan layak digunakan pada matakuliah TABM. Hal ini dilihat dari hasil validasi oleh ahli materi, ahli bahan ajar, dan uji coba kelompok kecil yang masingmasing memperoleh persentase kevalidan sebesar 95,40\%, 99,49\% dan 86,35\%. 2) Nilai aktivitas fosforilasi protein membran spermatozoa kambing PE pada BM 43 kDa lebih besar dibandingkan dengan nilai aktivitas fosforilasi protein membran spermatozoa kambing Boer. Pada kambing PE jumlah ATP yang difosforilasi sebesar 179 ppm, sedangkan pada kambing Boer sebesar 159,5 ppm. Unit aktivitas fosforilasi protein membran spermatozoa pada berat molekul $43 \mathrm{kDa}$ sebesar $69,29 \mathrm{x}$ $10^{-2} \mu \mathrm{mol} / \mathrm{mL}$.menit, sedangkan pada kambing Boer sebesar 61,61 x 10${ }^{2} \mu \mathrm{mol} / \mathrm{mL}$. menit.

\section{SARAN}

Saran pemanfaatan produk yaitu 1) modul berbasis penelitian analisis aktivitas fosforilasi hendaknya dapat dimanfaatkan sebagai bahan ajar mandiri yang digunakan pada matakuliah TABM, 2) modul dapat dijadikan sebagai penunjang bahan ajar selain buku teks yang dapat memandu mahasiswa untuk mengetahui petunjuk praktis dalam melakukan kegiatan laboratorium, 3) modul berbasis penelitian analsis aktivitas fosforilasi protein membran spermatozoa diharapkan dapat dijadikan sebagai dasar dalam memberikan informasi mengenai kualitas sperma secara molekuler.

\section{Saran}

Modul yang dikembangkan dalam penelitian ini tidak sampai pada tahap diseminasi, namun jika ingin dilakukan diseminasi maka produk perlu diterapkan pada kegiatan pembelajaran dengan jumlah subjek uji coba yang lebih banyak. Penggunaan modul yang diterapkan pada perkuliahan TABM hendaknya bertujuan untuk memecahkan permasalahan yang berkaitan dengan pencapaian kompetensi dasar matakuliah TABM, 2) modul berbasis penelitian yang telah diujicobakan dalam rangka mengatasi permasalahan pembelajaran sebaiknya dilaporkan hasil uji cobanya melalui sebuah kegiatan diseminasi dan disertai dengan penyebaran produk yang telah direvisi berdasarkan hasil uji coba pada skala yang lebih luas.

Modul berbasis penelitian analisis aktivitas fosforilasi protein membran spermatozoa kambing dapat dikembangkan lagi materinya berdasarkan analisis aktivitas fosforilasi pada protein dengan berat molekul yang berbeda. Selain itu, produk pengembangan selanjutnya diharapkan dapat memuat prosedur laboratorium lebih lanjut berkaitan dengan identifikasi jenis protein yang memiliki aktivitas fosforilasi.

\section{DAFTAR PUSTAKA}

Akbar, S. (2013). Instrumen Perangkat Pembelajaran. Bandung. Remaja Rosdakarya.

Amin, M., Widodo, W., Pratiwi, R., Chandra, T., Sumartini. \& Sulastri, S. (2006). Panduan Pengembangan Bahan Ajar IPA. Jakarta: Direktorat Pembinaan Sekolah Menengah Pertama, Direktorat Jenderal Pendidikan Dasar dan Menengah, Departemen Pendidikan Nasional.

Arikunto, S. (2012). Dasar-Dasar Evaluasi Pendidikan Edisi 2. Jakarta: Rineka Cipta.

Aulanni'am. (2004). Prinsip dan Teknik Analisis Biomolekul. Malang: Fakultas Pertanian. Universitas Brawijaya Press. 
Brew, A. (2007). Imperatives and Challenges in Integrating Research and Teaching. Higher Education Research and Development, (Online), 29 (2) 139-150.

(http://www.tandf.co.uk/journa Is/pdf/freeaccess/HERDSA 201 1.pdf), diakses 12 Juni 2015.

Borg, W.R. \& Gall, M.D. (1983). Educational Research. New York: Longman Inc.

Campbell, N.A., Reece, J.B., Urry, L.A., Cain, M.L., Minorsky, P.V., Wasserman, S.A., \& Jackson, R.B. (2008). Biology Eighth Edition. US: Pearson Education.

Correa, J.R., Rodriquez, Petterson, Zavos. (1996). Thawing and Processing Spermatozoa at Various Temperatures and Their Effects on Sperm Viability, Osmotic Shock and Sperm Membrane Functional Integrity. Theriogenology. Volume 46.

Depdiknas. (2008). Panduan Pengembangan Bahan Ajar. Jakarta: Direktorat Jendral Manajemen Pendidikan Dasar dan Menengah.

Fatchiyah, Aruminingtyas, E. L., Widyarti, S. \& Rahayu, S. (2011). Biologi Molekular. Jakarta: Erlangga.

Katalog Jurusan Biologi Universitas Negeri Malang. (2013). Malang: Universitas Negeri Malang.

Keputusan Menteri Pendidikan Nasional Republik Indonesia No. 232/U/2000 Tahun 2000 tentang Pedoman Penyusunan Kurikulum Pendidikan Tinggi dan Penilaian Hasil Belajar Mahasiswa. (Online), (http://www.kopertis3.or.id/ht $\mathrm{ml} / \mathrm{wp}-$ content/uploads/2011/04/kep men-232-2000.pdf), diakses 21 Januari 2015.

Mulyasa. (2006). Implementasi Kurikulum 2004. Bandung:Rosdakarya.

Nath, D., B moumik, A., Das, S., Bhattacharyya, D., Dungdung, S.D. \& Majumder, G.C. (2012). A Novel Membrane ProteinSpecific Serine/Threonine Kinase: Tissue Distribution and Role in Sperm Maturation. Urology,

(Online),(http://www.hindawi.c om/journals/isrn/2012/789105/ ), diakses 21 Januari 2015

Nath, D., Maiti, A., \& Majumder, G.C. (2007). Cell Surface Phosphorylation by a Novel Ecto-Protein Kinase: a Key Regulator of Cellular Functions in Spermatozoa. Biochimica et Biophysica Acta 1778 (2008) 153-165. (Online), (www.sciencedirect.com), diakses 20 Juni 2015.

Nath, D., \& Majumder, G.C. (1999). Maturation-dependent

Modification of the Protein PhosphorylationProfile of Isolated Goat Sperm Plasma Membrane. Journal of Reproduction and Fertility. 115.29-37. (Online), (http://www.reproductiononline.org/content/115/1/29.fu II.pdf), diakses 21 Januari 2015.

Naz, R.K. \& Rajesh, P.B. (2004). Role of Tyrosine Phosphorylation in Sperm Capacitation/Acrosome Reaction. Reprod. Biol. Endo. 2:1-12. (Online), (http://www.ncbi.nlm.nih.gov/p mc/articles/PMC533862/), diakses 21 Januari 2015.

Pamungkas, F.A. (2009). Potensi Dan Kualitas Semen Kambing Dalam 
Rangka Aplikasi Teknologi Inseminasi Buatan,(Online), (http://peternakan.litbang.pert anian.go.id/fullteks/wartazoa/w azo191-3.pdf?secure=1), diakses 22 Juni 2015.

Prastowo, A. (2011). Panduan Kreatif membuat Bahan Ajar Inovatif. Yogyakarta: Diva Press.

Purnama, D. (2014). Pengembangan Modul Berbasis Teknik Analisis Proteomik embran Spermatozoa Sapi (Bos sp) pada Matakuliah Teknik Analisis Biologi Molekuler di Universitas Negeri Malang. Tesis tidak diterbitkan. Malang: Pascasarjana UM.

Sherwood, L. (2014). FisiologiManusia. Terjemahan Brahm, U.P. 2011. Jakarta: EGC.

Suharno, B. \& Syukur, A. (2014). Bisnis pembibitan Kambing. Jakarta: Penebar Swadaya.

Tambing, S.N., \& Sariubang, M. (2008). Kajian Komponen Teknologi Inseminasi Buatan(IB) Pada Induk Kambing, (Online), (http://peternakan.litbang.pert anian.go.id/fullteks/semnas/pro 08-83.pdf?secure=1), diakses 7 Juni 2015.

Thieman, W.J. \& Palladino, M.A. (2013). Introduction to Biotechnology Third edition. US: Pearson.

Urner, F. \& Sakkas, D. (2003). Protein Phosphorylation in Mammalian Spermatozoa. Reproduction (125): 17-26, (Online), (http://www.reproductiononline.org/content/125/1/17.fu II.pdf), diakses 19 Juni 2015 